\title{
The Effect of Planting Time on Phytophthora Blight Disease Incidence and Severity on Cucumber (Cucumis sativus) in Nsukka, Derived Savanna, Agro Ecology, South Eastern Nigeria
}

Patience Ukamaka Ishieze*, Ugwuoke Kelvin I and Aba Simon C

Department of Crop science, University of Nigeria, Nsukka

\begin{abstract}
Field experiments were conducted to study the disease incidence and severity of six cucumber lines at different time of planting (April, $12^{\text {th }}$; May, $12^{\text {th }} ;$ June, $12^{\text {th }}$, July, $12^{\text {th }}$ and September, $12^{\text {th }}$ ), Six varieties of cucumber (Marketter, Poinsett 76 Netherlands, Poinsett 76 Holland, Poinsett France, Poinsett Holland and super marketter) during 2013 farming season. It was observed from the results that the planting time of April had the lowest disease incidence $(3.48 \%)$ and severity on leaves (1.20) and fruits (1.06), followed by September with lower disease incidence $(3.60 \%)$, disease severity on leaves (1.22) and fruits (1.17) while July had the highest disease incidence $(6.27 \%)$ and disease severity on leaves(1.56) and fruits (1.74). The yields during the April and September plantings were significantly $(p<0.05)$ higher than other months. April and September had 481.60 and 483.60 tonnes per hectare respectively while July had 19.10 tonnes per hectare. The cucumber lines also showed.

significant $(\mathrm{p}<0.05)$ response to disease incidence and severity with the Supermarketer having the lowest disease incidence $(4.15 \%)$ and severity on leaves (1.39) and fruits (1.17) and Poinsette Holland had the highest disease incidence $(5.15 \%)$ and Poinsette 76 Holland had the highest severity both on leaves and fruits $(1.45$ and 1.35). The supermarketer gave the highest yield of 221.10 tonnes per hectare. From the observations farmers in derived savanna agro ecology can plant during the month of April and September for maximum yield and less usage of pesticides. Super marketer variety remains the best variety in this study.
\end{abstract}

Keywords: Disease incidence; Disease severity; Time of planting; Cucumber

\section{Introduction}

Cucumber (Cucumis sativus L.) belongs to the Cucurbitaceae family. Cucumber is a major vegetable crop worldwide and develops rapidly, with a shorter time from planting to harvest than for most crops [1]. It is a monoecious annual climber or creeper [2] that has been cultivated for over 3,000 years and is still widely cultivated today. It is soft, succulent with high water content. The plant has large leaves that form canopy over the fruit. The vines grow on stakes or on trellises. The fruit is roughly cylindrical, elongated with tapered ends and may be as long in diameter. The fruits are used in unripe matured state, usually eaten raw in salads or pickled, and are also stewed in tropical regions. Although cucumber is less nutritious than most fruits, it is still a very good source of vitamins $\mathrm{A}, \mathrm{C}, \mathrm{K}, \mathrm{B} 6$, potassium and it also provides dietary fibres, pantothenic acid, magnesium, phosphorus, copper and manganese. It contains ascorbic acid and caffeic acid, both of which help to smoothen the skin irritation and reduces swelling. Its skin contains chlorophyll and silica, two beneficial elements that are lost when the vegetables are peeled. Its juice is often recommended as a source of silicon to improve the complexion and health of the skin. However, the production of the fruit in Nigeria is very low due to some constraints such as incidences of disease, which reduces pod yield. They are produced mainly in the northern states of Nigeria [2]. It is necessary to increase the production in order to supplement the high intake of carbohydrate in Nigeria, especially the southern parts of Nigeria where there is sparse and over dependence of its supply of salad vegetables and fruits on major suppliers from the north, resulting to relative higher price because of transportation cost and spoilage in the transportation of the fruit. The fruit constitute the dietary system of the populace in the cities as valuable ingredient in vegetable salads and fruit.
In Nigeria, adequate research has not been conducted to find out the best time to plant, fungicides and spray regimes to control the disease outbreak, which is common in the south due to warm weather. Fruit is usually under foliage, shading one another being allowed to creep on the ground thereby having a direct contact with some soil inhabiting disease-causing organisms. Because of its creeping nature, it pre disposes the plant for pests and disease infestation. Torrential rainfall sometimes splash sand on edible pod yield, leading to outright degradation of the market quality of pods.

\section{Materials and Methods}

The experiments was conducted at the Department of Crop Science Teaching and Research Farm, Faculty of Agriculture, University of Nigeria, Nsukka $\left(07^{\circ} 29 \mathrm{~N}, 06^{\circ} 51 \mathrm{E}\right.$ and 400 m.a.s.l.). Nsukka is characterized by lowland humid tropical conditions with bimodal rainfall pattern which starts in late March and ends in late July while the short rainy season extends from September to late October after a dry spell in August. It ranges between $1155 \mathrm{~mm}$ to $1955 \mathrm{~mm}$ with a mean annual temperature of $29^{\circ} \mathrm{C}$ to $31^{\circ} \mathrm{C}$ and a relative humidity of $69 \%$ to $79 \%$.

*Corresponding author: Patience Ukamaka Ishieze, Department of Crop science, University of Nigeria, Nsukka, Tel: +2348035271306; E-mail: makcynthia2003@yahoo.com

Received November 06, 2015; Accepted November 23, 2015; Published November 29, 2015

Citation: Ishieze PU, Ugwuoke Kelvin I, Aba Simon C (2015) The Effect of Planting Time on Phytophthora Blight Disease Incidence and Severity on Cucumber (Cucumis sativus) in Nsukka, Derived Savanna, Agro Ecology, South Eastern Nigeria. J Plant Pathol Microbiol 6: 318. doi:10.4172/2157-7471.1000318

Copyright: @ 2015 Ishieze PU, et al. This is an open-access article distributed under the terms of the Creative Commons Attribution License, which permits unrestricted use, distribution, and reproduction in any medium, provided the original author and source are credited. 
Citation: Ishieze PU, Ugwuoke Kelvin I, Aba Simon C (2015) The Effect of Planting Time on Phytophthora Blight Disease Incidence and Severity on Cucumber (Cucumis sativus) in Nsukka, Derived Savanna, Agro Ecology, South Eastern Nigeria. J Plant Pathol Microbiol 6: 318. doi:10.4172/2157-7471.1000318

\section{Field experiment}

This experiment evaluated the effect of planting time on disease incidence, severity and pod yield on the six cucumber lines. The planting were carried out for a period of five months starting from April $12^{\text {th }}$ through May $12^{\text {th }}$, to July $12^{\text {th }}$ and September $12^{\text {th }}$.

Six cucumber lines including Super marketer, Poinsett France, Poinsett Holland, Poinsett 76 Holland, Poinsett 76 Netherlands and Marketer were used in the study. At each planting, the experiment was laid out in randomized complete block design (RCBD) of three replications

A portion of land measuring $320 \mathrm{~m}^{2}$ was cleared, ploughed and harrowed, before seed beds measuring $2 \mathrm{~m} \times 3 \mathrm{~m}$ was prepared. The seeds were sown insitu at two seeds per hill at a spacing of $10 \mathrm{~cm}$ within rows and $20 \mathrm{~cm}$ between rows with planting depth of $2.5 \mathrm{~cm}$ on each bed. Prior to the planting, battery cage poultry manure was applied at 3 tonnes per hectare on the readymade bed, one week before planting.

\section{Data collection}

In data collection the disease incidence and severity at 2, 4, 6, 8 and 10 weeks after planting and interaction of the various spray regimes used to check the disease incidence measured as percentage of plants showing visible symptom of phytophtora blight, disease severity and pod yield were collected. Disease severity (the proportion of area or amount of plant tissue that is diseased) on both leaves and fruits was also calculated in percentage and was later rated see Table 2 . The following parameters were measured to determine the level of disease incidence and severity on these cucumber accessions keeping in mind some developmental qualities:

- Disease incidence at 2 weeks, 4 weeks, 6 weeks, 8 weeks and 10 weeks after planting.

- Disease severity on leaves at $2,4,6,8$, and 10 weeks after planting

- Disease severity on fruits at 6,8 , and 10 weeks after planting

- Variety response to disease incidence

- Variety response to disease severity on leaves

- Variety response to disease severity on fruits

- Yield per plant $(\mathrm{kg})$

\section{Laboratory analysis}

Apart from the visible signs of phytophthora blight, the diseased plant tissues were taken to the laboratory where they were cultured to know the fungal organism present. A strip of transparent sticky tape (10 $\mathrm{cm}$ long) is held in between the thumb and the forefinger. The sticky side of the tape is firmly pressed onto the surface of the sporulating colony cultivated on an appropriate medium in the Petri dish. After gently removing the cellophane tape, the sticky surface carrying fungal spores is carefully placed over drops of lacto phenol cotton blue stain kept at the centre of a clean glass slide. The tape is gently pressed and extended end of the tape was held over the ends of the slide. A light microscope $40 \mathrm{~m}$ magnification was used to examine the characteristics of spores.

\section{Data analysis}

Data collected were subjected to analysis of variance (ANOVA) using GenStat 10th edition release statistical software. Mean separation was done using Fishers least significance test at 5\% probability level as described by Obi [3].

\section{Results and Discussion}

\section{Meteorological data of 2013 planting season}

The meteorological data from the experimental site shows that there is a marked variation on the climatic elements being considered (Table 1). The distribution of rainfall shows the total rainfall $(1537.28 \mathrm{~mm})$ received during the period of the experiment (January to December 2013) with the highest rainfall amount and rain days being in July (283.96 $\mathrm{mm}$ and 19days) respectively. Moreover, the mean minimum and maximum temperatures were $21.14^{\circ} \mathrm{C}$ and $29.54^{\circ} \mathrm{C}$ for the year. The data also reveal that the mean monthly relative humidity at $10 \mathrm{a} . \mathrm{m}$. and 4 p.m. were $74.67 \%$ and $72.64 \%$ respectively for the year.

\section{Aboratory results}

The plant tissue analysed showed that there was growth of spores, which indicates the presence of fungal organism. When the characteristics of the spores were examined, the colour as observed showed that the organism present is Phythophtora capsici, the causal organism for phythophtora blight of cucumber.

The effect of planting time on incidence, severity on phytophtora blight disease leaves and fruits at 2, 4, 6, 8, and 10 weeks after planting on the six cucumber lines studied.

The results of the effect of planting time on the phytophtora blight disease incidence on six cucumber presented in Table 3 revealed that the month of July significantly (0.05) had the highest phytophtora disease (6.27\%), followed closely by the month of May and June $(5.57 \%$ and $5.31 \%)$ respectively. The disease incidence was lowest in April, followed by September (3.48\% and $4.85 \%$ respectively). From the results, it shows that the best time to plant is April and September.

\begin{tabular}{|c|c|c|c|c|c|c|}
\hline Month & $\begin{array}{c}\text { Total rainfall } \\
(\mathbf{m m})\end{array}$ & $\begin{array}{c}\text { Rain } \\
\text { day }\end{array}$ & \multicolumn{2}{|c|}{ Temperature $\left({ }^{\circ} \mathbf{C}\right)$} & \multicolumn{2}{|c|}{$\begin{array}{c}\text { Relative humidity } \\
(\mathbf{\%})\end{array}$} \\
\hline & & & $\mathbf{m i n i}$ & $\mathbf{m a x}$ & $\mathbf{1 0}$ a.m. & $\mathbf{4}$ p.m. \\
\hline January & 21.84 & 2.00 & 20.55 & 31.23 & 75.00 & 75.00 \\
\hline February & 0.00 & 0.00 & 22.18 & 32.86 & 75.00 & 75.00 \\
\hline March & 38.10 & 5.00 & 22.58 & 32.81 & 72.74 & 62.94 \\
\hline April & 183.81 & 10.00 & 22.30 & 30.67 & 74.00 & 68.90 \\
\hline May & 198.63 & 11.00 & 21.61 & 29.52 & 74.77 & 69.87 \\
\hline June & 168.60 & 11.00 & 21.17 & 28.67 & 75.67 & 72.70 \\
\hline July & 283.96 & 19.00 & 20.71 & 27.35 & 74.90 & 73.61 \\
\hline August & 219.18 & 12.00 & 20.26 & 26.61 & 76.13 & 76.16 \\
\hline September & 197.60 & 16.00 & 20.50 & 27.43 & 77.00 & 77.00 \\
\hline October & 167.90 & 11.00 & 20.74 & 28.55 & 77.00 & 77.00 \\
\hline November & 41.91 & 2.00 & 21.70 & 30.37 & 77.00 & 77.00 \\
\hline December & 15.75 & 2.00 & 19.39 & 29.35 & 66.77 & 66.03 \\
\hline Total & 1537.28 & 101.00 & 253.69 & 354.42 & 895.98 & 871.66 \\
\hline Mean & 128.10 & 8.42 & 21.14 & 29.54 & 74.67 & 72.64 \\
\hline
\end{tabular}

Table 1: The total rainfall $(\mathrm{mm})$, rain days, mean temperature $\left({ }^{\circ} \mathrm{C}\right)$ and the relative humidity (\%) of the site of the experiment in 2013.

\begin{tabular}{|c|c|}
\hline Ratings & Percentage \\
\hline 0 & 0 \\
\hline 1 & $1-25$ \\
\hline 2 & $26-50$ \\
\hline 3 & $51-75$ \\
\hline 4 & $76-100$ \\
\hline
\end{tabular}

Table 2: Disease severity Ratings. 
Citation: Ishieze PU, Ugwuoke Kelvin I, Aba Simon C (2015) The Effect of Planting Time on Phytophthora Blight Disease Incidence and Severity on Cucumber (Cucumis sativus) in Nsukka, Derived Savanna, Agro Ecology, South Eastern Nigeria. J Plant Pathol Microbiol 6: 318. doi:10.4172/2157-7471.1000318

Page 3 of 8

\begin{tabular}{|c|c|c|c|c|c|c|c|c|c|c|c|c|}
\hline \multicolumn{10}{|c|}{ WEEKS AFTER PLANTING (WAP) } \\
\hline MONTH & \multicolumn{2}{|c|}{ 2WAP } & \multicolumn{2}{c|}{ 4WAP } & \multicolumn{2}{c|}{ 6WAP } & \multicolumn{2}{c|}{ 8WAP } & \multicolumn{3}{c|}{ 10WAP } & \multicolumn{1}{c|}{ MEAN } \\
\hline APRIL & 8.060 & $(2.419)$ & 11.530 & $(3.139)$ & 15.280 & $(3.667)$ & 15.970 & $(3.825)$ & 19.720 & $(4.360)$ & 14.112 & $(3.482)$ \\
\hline MAY & 8.610 & $(2.733)$ & 24.310 & $(4.860)$ & 30.420 & $(5.475)$ & 35.970 & $(5.988)$ & 78.610 & $(8.810)$ & 35.584 & $(5.573)$ \\
\hline JUNE & 11.670 & $(3.274)$ & 17.220 & $(3.900)$ & 18.750 & $(4.127)$ & 40.000 & $(6.311)$ & 80.560 & $(8.954)$ & 33.640 & $(5.313)$ \\
\hline JULY & 11.670 & $(3.274)$ & 17.220 & $(3.900)$ & 18.750 & $(4.127)$ & 100.000 & $(10.025)$ & 100.000 & $(10.025)$ & 49.528 & $(6.270)$ \\
\hline SEPT & 5.970 & $(2.099)$ & 12.08 & $(3.245)$ & 15.690 & $(3.762)$ & 16.810 & $(4.015)$ & 24.030 & $(4.898)$ & 14.916 & $(3.604)$ \\
\hline MEAN & 9.196 & $(2.760)$ & 16.472 & $(3.809)$ & 19.778 & $(4.232)$ & 41.750 & $(6.033)$ & 60.584 & $(7.415)$ & 29.556 & $(4.849)$ \\
\hline F-LSD(0.05) & & 0.4025 & & 0.3673 & & 0.3347 & & 0.2429 & & 0.2413 & \\
\hline
\end{tabular}

Values in parenthesis are square root transformed values to which LSD is applicable.

Table 3: The main effect of planting time on phytophtora blight disease incidence on the six cucumber lines at different weeks after planting.

\begin{tabular}{|c|c|c|c|c|c|c|c|c|c|c|c|c|}
\hline \multicolumn{13}{|c|}{ WEEKS AFTER PLANTING (WAP) } \\
\hline MONTH & \multicolumn{2}{|c|}{ 2WAP } & \multicolumn{2}{|c|}{ 4WAP } & \multicolumn{2}{|c|}{ 6WAP } & \multicolumn{2}{|c|}{ 8WAP } & \multicolumn{2}{|c|}{ 10WAP } & \multicolumn{2}{|c|}{ MEAN } \\
\hline APRIL & 0.708 & $(1.056)$ & 0.986 & $(1.188)$ & 1.042 & $(1.219)$ & 1.097 & $(1.248)$ & 1.194 & $(1.294)$ & 1.005 & $(1.201)$ \\
\hline MAY & 0.736 & $(1.088)$ & 1.333 & $(1.343)$ & 2.111 & $(1.591)$ & 2.306 & $(1.640)$ & 3.986 & $(2.118)$ & 2.094 & $(1.556)$ \\
\hline JUNE & 0.875 & $(1.158)$ & 0.944 & $(1.189)$ & 1.028 & $(1.223)$ & 2.306 & $(1.640)$ & 4.000 & $(2.121)$ & 1.831 & $(1.466)$ \\
\hline JULY & 0.875 & $(1.158)$ & 0.944 & $(1.189)$ & 1.028 & $(1.223)$ & 4.000 & $(2.121)$ & 4.000 & $(2.121)$ & 2.169 & $(1.562)$ \\
\hline SEPT & 0.514 & $(0.973)$ & 1.042 & $(1.213)$ & 1.167 & (1.284) & 1.181 & (1.289) & 1.389 & (1.363) & 1.059 & $(1.224)$ \\
\hline MEAN & 0.742 & $(1.087)$ & 1.050 & $(1.224)$ & 1.275 & (1.308) & 2.178 & $(1.588)$ & 2.914 & $(1.803)$ & 1.632 & $(1.402)$ \\
\hline F-LSD(0.05) & & 0.0653 & & 0.0589 & & 0.0607 & & 0.0681 & & 0.0305 & & \\
\hline
\end{tabular}

Values in parenthesis are square-root transformed values to which LSD is applicable.

Table 4: The main effect of planting time on Phytophtora blight disease severity on leaves of the six cucumber lines at different weeks after planting

\begin{tabular}{|c|c|c|c|c|c|c|c|c|c|c|c|c|}
\hline \multicolumn{13}{|c|}{ WEEKS AFTER PLANTING (WAP) } \\
\hline \multirow{2}{*}{$\begin{array}{c}\text { MONTH } \\
\text { APRIL }\end{array}$} & \multicolumn{2}{|c|}{ 2WAP } & \multicolumn{2}{|c|}{ 4WAP } & \multicolumn{2}{|c|}{ 6WAP } & \multicolumn{2}{|c|}{ 8WAP } & \multicolumn{2}{|c|}{ 10WAP } & \multicolumn{2}{|c|}{ MEAN } \\
\hline & - & - & - & - & 0.556 & $(0.990)$ & 0.722 & $(1.067)$ & 0.806 & $(1.112)$ & 0.695 & $(1.056)$ \\
\hline MAY & - & - & - & - & 0.958 & $(1.164)$ & 1.722 & $(1.470)$ & 1.431 & $(1.376)$ & 1.370 & $(1.337)$ \\
\hline JUNE & - & - & - & - & 0.528 & $(0.978)$ & 0.681 & $(1.057)$ & 1.458 & $(1.387)$ & 0.889 & $(1.141)$ \\
\hline JULY & - & - & - & - & 0.528 & $(0.978)$ & 4.000 & $(2.121)$ & 4.000 & $(2.121)$ & 2.843 & (1.740) \\
\hline SEPT & - & - & - & - & 0.694 & $(1.064)$ & 0.986 & (1.209) & 1.069 & (1.249) & 0.916 & $(1.174)$ \\
\hline MEAN & & - & & - & 0.653 & $(1.035)$ & 1.622 & (1.385) & 1.753 & (1.449) & 1.343 & (1.290) \\
\hline F-LSD(0.05) & & & & & & 0.0841 & & 0.0635 & & 0.0543 & & \\
\hline
\end{tabular}

Values in parenthesis are square-root transformed values to which LSD is applicable.

Table 5: The main effect of planting time on Phytophtora blight disease severity on Fruits of the six cucumber lines at different weeks after planting

The results of the effect planting time on the phytophtora blight disease severity on cucumber presented in Table 4 revealed that the month of July significantly $(0.05)$ had the most severe phytophtora disease $(1.56 \%)$, followed closely by the month of May and June (1.56\% and $1.47 \%)$ respectively. The severity of phytophtora blight of cucumber was lowest in April, followed by September $(1.20 \%$ and $1.22 \%$ respectively). From the results, it shows that the best time to plant with lowest disease severity on leaves is April and September.

Table 5 shows the results of the effect of planting time on the phytophtora blight disease severity on cucumber fruits and it revealed that the month of July significantly $(0.05)$ had the most severe phytophtora blight disease on the fruits $(1.74 \%)$, followed closely by the month of May and September $(1.34 \%$ and $1.17 \%)$ respectively. The severity of phytophtora blight of cucumber was lowest in April, followed by June (1.06\% and $1.14 \%$ respectively). From the results, it shows that the best time to plant with lowest disease severity on Fruits is April and June.

Table 6 revealed that the yield during the April and September planting were significantly (0.05) higher than other months. April and
September recorded 481.60 and 483.60 tonnes per hectare respectively while May, June, July was 35.50, 32.30 and 19.10 tonnes per hectare respectively. The fruit girth, number of fruits per plant, fruit weight and fruit length were also statistically significant $(0.05)$ and it also followed the above trend of April and September being the best and July having the lowest girth, length, number of fruits per plant, fruit weight and diseased fruits.

The effect of the six cucumber lines on the manifestation of phytophtora blight disease incidence, severity on leaves and fruits at $2,4,6,8$, and 10 weeks after planting for all the planting times considered.

In Table 7, the different lines of cucumber significantly affected the rate of disease incidence. The poinsett Holland $\mathrm{PH}$, Poinsett 76 Holland P76H, Poinsett France PF, Poinsett 76 Netherland P76N, recorded higher incidences, $(5.15,5.15,5.05$ and 4.81$)$ percentage respectively while marketer $\mathrm{M}$ and super marketer SM had a lower incidence at 4.79 and $4.15 \%$ respectively. The varieties when compared reveal that the super marketer is the best cucumber line that can resist phytophtora blight disease in this derived savannah. 
Citation: Ishieze PU, Ugwuoke Kelvin I, Aba Simon C (2015) The Effect of Planting Time on Phytophthora Blight Disease Incidence and Severity on Cucumber (Cucumis sativus) in Nsukka, Derived Savanna, Agro Ecology, South Eastern Nigeria. J Plant Pathol Microbiol 6: 318. doi:10.4172/2157-7471.1000318

Page 4 of 8

\begin{tabular}{|c|c|c|c|c|c|c|}
\hline MONTH & $\mathrm{FG}(\mathrm{cm})$ & $\mathrm{FL}(\mathrm{cm})$ & FW/PIt(kg) & NFPP & FY(t/ha) & DF(t/ha) \\
\hline APRIL & 5.162 & 20.010 & 2.408 & 5.505 & 481.6 & 2.408 \\
\hline MAY & 2.383 & 12.359 & 0.178 & 2.271 & 35.5 & 0.178 \\
\hline JUNE & 2.556 & 11.608 & 0.161 & 2.146 & 32.3 & 0.161 \\
\hline JULY & 2.440 & 11.608 & 0.095 & 1.982 & 19.1 & 0.095 \\
\hline SEPT & 5.162 & 20.010 & 2.443 & 5.577 & 483.6 & 2.419 \\
\hline MEAN & 3.541 & 15.119 & 1.057 & 3.496 & 210.420 & 1.052 \\
\hline F-LSD(0.05) & 0.1392 & 0.2097 & 0.0717 & 0.2023 & 12.92 & 0.0625 \\
\hline
\end{tabular}

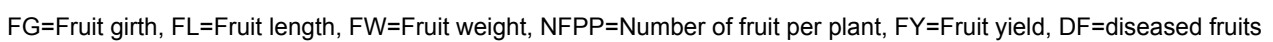

Table 6: The effect of planting time on some yield parameters of the six cucumber lines.

\begin{tabular}{|c|c|c|c|c|c|c|c|c|c|c|c|c|}
\hline \multicolumn{13}{|c|}{ WEEKS AFTER PLANTING (WAP) } \\
\hline VARIETY & \multicolumn{2}{|c|}{ 2WAP } & \multicolumn{2}{|c|}{ 4WAP } & \multicolumn{2}{|c|}{ 6WAP } & \multicolumn{2}{|c|}{ 8WAP } & \multicolumn{2}{|c|}{ 10WAP } & \multicolumn{2}{|c|}{ MEAN } \\
\hline M & 9.000 & $(2.707)$ & 17.000 & $(3.914)$ & 19.170 & $(4.191)$ & 39.330 & $(5.735)$ & 61.170 & $(7.424)$ & 29.134 & $(4.794)$ \\
\hline $\mathrm{P} 76 \mathrm{H}$ & 10.670 & $(3.085)$ & 20.170 & $(4.296)$ & 22.330 & $(4.586)$ & 42.500 & $(6.130)$ & 64.000 & (7.632) & 31.934 & $(5.146)$ \\
\hline $\mathrm{P} 76 \mathrm{~N}$ & 10.500 & $(2.919)$ & 14.330 & $(3.561)$ & 18.500 & $(4.112)$ & 42.000 & $(6.080)$ & 60.000 & (7.380) & 29.066 & $(4.810)$ \\
\hline PF & 8.830 & $(2.820)$ & 18.170 & $(4.061)$ & 22.500 & $(4.591)$ & 43.670 & $(6.219)$ & 62.170 & $(7.571)$ & 31.068 & $(5.052)$ \\
\hline $\mathrm{PH}$ & 9.830 & $(2.849)$ & 19.170 & $(4.119)$ & 23.830 & $(4.646)$ & 46.000 & $(6.492)$ & 63.500 & $(7.643)$ & 32.466 & $(5.150)$ \\
\hline SM & 6.330 & $(2.177)$ & 10.000 & $(2.903)$ & 12.330 & $(3.265)$ & 37.000 & $(5.541)$ & 52.670 & $(6.844)$ & 23.666 & (4.146) \\
\hline MEAN & 9.193 & 2.760 & 16.473 & 3.809 & 19.777 & 4.232 & 41.750 & 6.033 & 60.585 & 7.416 & 29.556 & $(4.850)$ \\
\hline F-LSD(0.05) & & 0.4409 & & 0.4024 & & 0.3667 & & 0.2661 & & 0.2643 & & \\
\hline
\end{tabular}

$\mathrm{M}=$ Marketer,P76H=Poinsett 76 Holland, $\mathrm{P} 76 \mathrm{~N}=$ Poinsett 76 Netherlands, PF=Poinsett France,PH=Poinsett Holland, S=Super marketer. Values in parenthesis are squareroot transformed values to which LSD is applicable.

Table 7: The main effect of the six cucumber lines on phytophtora blight disease incidence at different weeks after planting for the five planting times considered

\begin{tabular}{|c|c|c|c|c|c|c|c|c|c|c|c|c|}
\hline \multicolumn{13}{|c|}{ WEEKS AFTER PLANTING (WAP) } \\
\hline VARIETY & \multicolumn{2}{|c|}{ 2WAP } & \multicolumn{2}{|c|}{ 4WAP } & \multicolumn{2}{|c|}{ 6WAP } & \multicolumn{2}{|c|}{ 8WAP } & \multicolumn{2}{|c|}{ 10WAP } & \multicolumn{2}{|c|}{ MEAN } \\
\hline M & 0.583 & $(1.006)$ & 1.000 & $(1.211)$ & 1.333 & (1.325) & 2.567 & (1.694) & 2.950 & $(1.816)$ & 1.687 & (1.410) \\
\hline $\mathrm{P} 76 \mathrm{H}$ & 0.750 & $(1.090)$ & 1.200 & $(1.293)$ & 1.450 & $(1.377)$ & 2.433 & (1.673) & 2.933 & $(1.810)$ & 1.753 & (1.449) \\
\hline P76N & 0.700 & $(1.069)$ & 0.933 & $(1.180)$ & 1.167 & $(1.272)$ & 1.933 & $(1.515)$ & 2.900 & (1.798) & 1.527 & $(1.367)$ \\
\hline PF & 0.917 & $(1.171)$ & 1.233 & $(1.291)$ & 1.333 & $(1.338)$ & 2.050 & $(1.548)$ & 2.933 & $(1.810)$ & 1.693 & (1.432) \\
\hline $\mathrm{PH}$ & 0.833 & $(1.136)$ & 1.200 & $(1.284)$ & 1.367 & $(1.336)$ & 2.233 & $(1.608)$ & 2.950 & $(1.816)$ & 1.717 & (1.436) \\
\hline SM & 0.667 & $(1.047))$ & 0.733 & $(1.087)$ & 1.000 & $(1.203)$ & 1.850 & (1.488) & 2.817 & $(1.770)$ & 1.413 & $(1.387)$ \\
\hline MEAN & 0.742 & $(1.094)$ & 1.050 & $(1.224)$ & 1.275 & (1.309) & 2.178 & $(1.588)$ & 2.914 & $(1.803)$ & 1.632 & (1.404) \\
\hline F-LSD & & 0.0715 & & 0.0645 & & 0.0665 & & 0.0746 & & NS & & \\
\hline
\end{tabular}

$\mathrm{M}=$ Marketer, $\mathrm{P} 76 \mathrm{H}=$ Poinsett 76 Holland, P76N=Poinsett 76 Netherlands, PF=Poinsett France, $\mathrm{PH}=$ Poinsett Holland, $\mathrm{S}=\mathrm{Super}$ marketer. Values in parenthesis are squareroot transformed values to which LSD is applicable.

Table 8: The main effects of the six cucumber lines on disease severity on leaves at different weeks after planting for the five planting times considered.

\begin{tabular}{|c|c|c|c|c|c|c|c|c|c|c|c|c|}
\hline \multicolumn{10}{|c|}{ WEEKS AFTER PLANTING (WAP) } \\
\hline VARIETY & \multicolumn{2}{|c|}{ 2WAP } & \multicolumn{2}{c|}{ 4WAP } & \multicolumn{2}{c|}{ 6WAP } & \multicolumn{2}{c|}{ 8WAP } & \multicolumn{2}{c|}{ 10WAP } & \multicolumn{2}{c|}{ MEAN } \\
\hline M & - & - & - & - & 0.717 & $(1.073)$ & 1.667 & $(1.392)$ & 1.733 & $(1.446)$ & 1.372 & $(1.304)$ \\
\hline P76H & - & - & - & - & 0.917 & $(1.167)$ & 1.667 & $(1.421)$ & 1.750 & $(1.454)$ & 1.445 & $(1.347)$ \\
\hline P76N & - & - & - & - & 0.483 & $(0.952)$ & 1.633 & $(1.388)$ & 1.750 & $(1.451)$ & 1.289 & $(1.264)$ \\
\hline PF & - & - & - & - & 0.733 & $(1.073)$ & 1.650 & $(1.406)$ & 1.783 & $(1.456)$ & 1.389 & $(1.312)$ \\
\hline PH & - & - & - & - & 0.817 & $(1.114)$ & 1.683 & $(1.404)$ & 1.933 & $(1.514)$ & 1.478 & $(1.344)$ \\
\hline SM & - & - & - & - & 0.250 & $(0.831)$ & 1.433 & $(1.296)$ & 1.567 & $(1.373)$ & 1.083 & $(1.167)$ \\
\hline MEAN & - & - & - & - & 0.653 & $(1.035)$ & 1.622 & $(1.385)$ & 1.753 & $(1.449)$ & 1.343 & $(1.290)$ \\
\hline F-LSD(0.05) & & - & & - & & 0.0921 & & 0.0696 & & 0.0596 & & \\
\hline
\end{tabular}

$\mathrm{M}=$ Marketer,P76H=Poinsett 76 Holland, P76N=Poinsett 76 Netherlands, PF=Poinsett France,PH=Poinsett Holland, S=Super marketer. Values in parenthesis are squareroot transformed values to which LSD is applicable.

Table 9: The main effect of the six cucumber lines on disease severity on fruit at different weeks after planting for the five planting times considered.

In Table 8 , the response of the six lines of cucumber to disease severity on leaves was statistically significant at $2,4,6,8$ weeks after planting but not significant at 10 weeks after planting. The mean disease severity recorded on the leaves was $1.41,1.45,1.37,1.43,1.44$, and 1.39 for M, P76H, P76N, PF, PH and SM respectively. From the table it indicates that super marketer can resist the phytophtora blight disease, that it is more severe on other varieties than the SM.

In Table 9, the response of the six lines of cucumber to disease severity on fruits was statistically significant at 6,8 and 10 weeks after planting. The mean disease severity recorded on the fruits was 1.30 , 
Citation: Ishieze PU, Ugwuoke Kelvin I, Aba Simon C (2015) The Effect of Planting Time on Phytophthora Blight Disease Incidence and Severity on Cucumber (Cucumis sativus) in Nsukka, Derived Savanna, Agro Ecology, South Eastern Nigeria. J Plant Pathol Microbiol 6: 318. doi:10.4172/2157-7471.1000318

Page 5 of 8

$1.35,1.26,1.31,1.34$, and 1.17 for $\mathrm{M}, \mathrm{P} 76 \mathrm{H}, \mathrm{P} 76 \mathrm{~N}, \mathrm{PF}, \mathrm{PH}$ and $\mathrm{SM}$ respectively. From the table it indicates that super marketer can give out fruits that shows less symptoms of phytophtora blight disease, that other varieties shows more severity of the aforementioned disease on their fruits than the SM.

In Table 10, the six-cucumber lines response to yield and number of fruit per plant was not significant but the fruit girth, fruit length and fruit weight was statistically significant. Though the yield of the supermarketer remains the best but the yield of all the lines and the number of fruits per plant and the bad/diseased fruits were not significant statistically.

The effect of planting time and variety on the phytophtora blight disease incidence, and severity on leaves and fruits at $2,4,6,8$, and 10 weeks after planting.

In Table 11, the interaction between the variety and time of planting on phytophtora blight disease incidence was not significant at 2,4 , and 10 weeks after planting, but were highly significant at 6 and 8 weeks after planting which was the onset of fruiting and also the peak of fruiting respectively. Super Marketer recorded the lowest disease incidence $(2.652 \%$ and $2.759 \%)$ at the month of April and September respectively, while the Poinsette France and Poinsette76 Holland recorded the highest disease incidence during the month of July (6.493 and 6.492 respectively). Showing from the arrays of mean displayed on the table, all varieties recorded lower disease incidence in the month of April and September, but the incidences were higher in the month of July. It is also high in May and slightly higher in June.

In Table 12, the interaction between the variety and time of planting on phytophtora blight disease severity on leaves was highly significant at 2, 4, 6 and 8 weeks after planting, but not significant at 10weeks after planting. The variety with highest disease severity (1.655) is the marketer during the month of May while the supermarketer recorded the lowest severity on the leaves (1.104) at the month of April. From the results obtained, the super marketer during the month of April had less severed diseased leaves thereby promoting photosynthetic ability and hence supplying the plant the needed growth nutrients for good yield and ability to resist the disease.

In Table 13, it was recorded that the interaction between the variety and time of planting on phytophtora blight disease severity on fruits was highly significant at 8 weeks after planting, but not significant at 6 and 10weeks after planting. The variety with highest severity (1.789) is the Poinsette 76 Holland during the month of July while the super marketer recorded the lowest severity on the fruits $(0.880)$ during the month of April. From the results, it showed that the super marketer is the best variety and planting during the month of April is the best time to apply while July remains the worst time to plant.
In Table 14, the data collected showed that the interaction between the month and the variety was not significant for the yield and the number of fruit per plant. From the yields recorded, the super marketer planted during the month of April and September remains the best variety and the best time to plant. It recorded 508 and 506 tonnes per hectare for April and September respectively. Where super marketer is not available, Poinsette Holland planted at the month of April can make for the best alternative.

\section{Discussion}

\section{Effects of planting time on phytophthora blight disease incidence, severity and the fruit yield of cucumber.}

The variation in the phytophthora blight disease incidence and severity on cucumber planted at various months of April, May, June, July and September indicates that April is the best time to plant in Nsukka Agro- ecology. The high yield experienced during the April planting over the May, June, July and September plantings could be attributed to moderate rainfall at the flowering and fruiting stage of the crop, which began in the middle of May. High rainfall during flowering and fruiting can lead to bees' inactivity with subsequent flower abortion with resultant low yield, which may have resulted in the yields experienced during the July planting. This is in agreement with the finding of Papadopoulos [4], who stated that high moisture tend to discourage the activity of bees and resultant high relative humidity which influence water condensing on the plant leaves which may result in the development of pests and diseases.

The significant $(\mathrm{p}<0.05)$ increase in disease incidence and severity during the month of July could be attributed to the high rainfall witnessed during that month $(283.96 \mathrm{~mm})$, low temperature and high relative humidity. These observations agrees with Babadoost, [5] that Phytophthora capsici causes pre and post-emergence damping-off in cucurbits under wet and warm $\left(20-30^{\circ} \mathrm{C}\right)$ weather condition, therefore the lower the temperature, the faster the growth of the spores which will in turn increase the disease incidences and severity with low yield. Soil moisture conditions are important for disease development. Sporangia form when soil pores are drained, and they release zoospores when soil is saturated (soil pores are filled with water). The disease is usually associated with heavy rainfall, excessive-irrigation, or poorly drained soil. Frequent irrigation increases the incidence of the disease. Warm conditions are favourable for disease development.

\section{The response of the six varieties of cucumber studied to phytophtora blight disease incidence, severity and yield}

The results of this study showed that there were significant differences among the six varieties of cucumber under study. In all cases, Super marketer, Poinsette 76 Netherlands and Marketer varieties

\begin{tabular}{|c|c|c|c|c|c|c|}
\hline VARIETY & $\mathbf{F G}(\mathrm{cm})$ & FL(cm) & FW/PIt(kg) & NFPP & FY(t/ha) & DF(t/ha) \\
\hline$M$ & 3.398 & 14.580 & 1.034 & 3.317 & 206.7 & 1.034 \\
\hline $\mathrm{P} 76 \mathrm{H}$ & 3.368 & 14.711 & 1.077 & 3.473 & 215.4 & 1.077 \\
\hline P76N & 3.462 & 15.151 & 1.001 & 3.477 & 200.1 & 1.001 \\
\hline PF & 3.639 & 15.170 & 1.058 & 3.575 & 211.6 & 1.058 \\
\hline $\mathrm{PH}$ & 3.515 & 14.857 & 1.037 & 3.519 & 207.5 & 1.037 \\
\hline SM & 3.860 & 16.245 & 1.136 & 3.616 & 221.1 & 1.107 \\
\hline MEAN & 3.540 & 15.119 & 1.057 & 3.496 & 210.400 & 1.052 \\
\hline F-LSD(0.05) & 0.1525 & 0.2297 & 0.0786 & 0.2216 & 14.1500 & 0.0547 \\
\hline
\end{tabular}

$\mathrm{M}=$ Marketer, $\mathrm{P} 76 \mathrm{H}=$ = Poinsett 76 Holland, $\mathrm{P} 76 \mathrm{~N}=$ Poinsett 76 Netherlands, $\mathrm{PF}=$ Poinsett France, $\mathrm{PH}=\mathrm{Poinsett}$ Holland, $\mathrm{S}=\mathrm{Super}$ marketer. FG=Fruit girth, FL=Fruit length, $\mathrm{FW}=$ Fruit weight, NFPP $=$ Number of fruit per plant and $\mathrm{FY}=$ Fruit yield, $\mathrm{DF}=$ Diseased fruits

Table 10: The Impact of varieties on Some Yield Parameters Considered on the five planting times considered. 
Citation: Ishieze PU, Ugwuoke Kelvin I, Aba Simon C (2015) The Effect of Planting Time on Phytophthora Blight Disease Incidence and Severity on Cucumber (Cucumis sativus) in Nsukka, Derived Savanna, Agro Ecology, South Eastern Nigeria. J Plant Pathol Microbiol 6: 318. doi:10.4172/2157-7471.1000318

\begin{tabular}{|c|c|c|c|c|c|c|c|c|c|c|c|c|}
\hline \multicolumn{13}{|c|}{ WEEKS AFTER PLANTING (WAP) } \\
\hline VARXMON & \multicolumn{2}{|c|}{ 2WAP } & \multicolumn{2}{|c|}{ 4WAP) } & \multicolumn{2}{|c|}{ 6WAP } & \multicolumn{2}{|c|}{ 8WAP } & \multicolumn{2}{|c|}{ 10WAP } & \multicolumn{2}{|c|}{ MEAN } \\
\hline MAPRIL & 5.830 & $(2.185$ & 7.500 & $(2.607)$ & 8.330 & $(2.714)$ & 8.330 & $(2.714)$ & 16.670 & $(4.013)$ & 9.332 & $(2.847)$ \\
\hline MMAY & 9.170 & (2.925) & 26.670 & $(5.141)$ & 32.500 & $(5.675)$ & 35.000 & $(5.922)$ & 81.670 & $(9.029)$ & 37.002 & $(5.738)$ \\
\hline MJUNE & 13.330 & (3.437) & 21.670 & (4.608) & 21.670 & $(4.608)$ & 39.170 & (6.236) & 83.330 & $(9.122)$ & 35.834 & $(5.602)$ \\
\hline MJULY & 13.330 & (3.437) & 21.670 & (4.608) & 21.670 & (4.608) & 100.000 & (10.025) & 100.000 & (10.025) & 51.334 & $(6.541)$ \\
\hline MSEPT & 3.330 & (1.552) & 7.500 & $(2.607)$ & 11.670 & (3.351) & 14.170 & (3.777) & 24.170 & $(4.929)$ & 12.168 & (3.243) \\
\hline P76HAPRIL & 11.670 & (3.082) & 14.170 & (3.611) & 17.500 & $(4.120)$ & 17.500 & (4.120) & 20.830 & (4.476) & 16.334 & (3.882) \\
\hline P76HMAY & 10.000 & (2.929) & 31.670 & $(5.589)$ & 34.170 & $(5.804)$ & 38.330 & (6.159) & 87.500 & $(9.326)$ & 40.334 & (5.961) \\
\hline P76HJUNE & 12.500 & (3.562) & 20.830 & (4.370) & 21.670 & (4.477) & 40.000 & (6.298) & 85.830 & (9.239) & 36.166 & (5.589) \\
\hline P76HJULY & 12.500 & (3.562) & 20.830 & (4.370) & 21.670 & (4.477) & 100.000 & (10.025) & 100.000 & (10.025) & 51.000 & (6.492) \\
\hline P76HSEPT & 6.670 & (2.292) & 13.330 & (3.541) & 16.670 & $(4.050)$ & 16.670 & $(4.050)$ & 25.830 & (5.095) & 15.834 & (3.806) \\
\hline P76NAPRIL & 10.000 & (2.764) & 10.830 & (2.975) & 15.830 & (3.802) & 16.670 & $(4.013)$ & 19.170 & (4.335) & 14.500 & (3.578) \\
\hline P76NMAY & 7.500 & (2.503) & 20.000 & (4.417) & 29.170 & (5.353) & 35.830 & (5.991) & 77.500 & (8.794) & 34.000 & (5.412) \\
\hline P76NJUNE & 13.330 & (3.358) & 14.170 & (3.611) & 15.830 & (3.802) & 40.830 & (6.360) & 80.830 & (8.984) & 32.998 & (5.223) \\
\hline P76NJULY & 13.330 & (3.358) & 14.170 & (3.611) & 15.830 & (3.802) & 100.000 & (10.025) & 100.000 & (10.025) & 48.666 & (6.164) \\
\hline P76NSEPT & 8.330 & (2.611) & 12.500 & (3.189) & 15.830 & (3.802) & 16.670 & (4.013) & 22.500 & (4.764) & 15.166 & (3.676) \\
\hline PFAPRIL & 5.000 & (1.974) & 14.170 & (3.446) & 19.170 & (4.108) & 20.000 & $(4.215)$ & 24.170 & $(4.831)$ & 16.502 & (3.715) \\
\hline PFMAY & 10.830 & (3.244) & 22.500 & (4.667) & 29.170 & (5.353) & 35.000 & (5.908) & 78.330 & (8.798) & 35.166 & (5.594) \\
\hline PFJUNE & 11.670 & (3.455) & 19.170 & (4.265) & 22.500 & (4.694) & 42.500 & (6.521) & 80.830 & (8.964) & 35.334 & (5.580) \\
\hline PFJULY & 11.670 & (3.455) & 19.170 & $(4.265)$ & 22.500 & (4.694) & 100.000 & $(10.025)$ & 100.000 & (10.025) & 50.668 & (6.493) \\
\hline PFSEPT & 5.000 & (1.974) & 15.830 & (3.661) & 19.170 & (4.108) & 20.830 & (4.426) & 27.500 & (5.236) & 17.666 & (3.881) \\
\hline PHAPRIL & 12.500 & (3.061) & 15.000 & (3.694) & 23.330 & (4.752) & 23.330 & $(4.752)$ & 24.170 & (4.835) & 19.666 & (4.219) \\
\hline PHMAY & 8.330 & (2.714) & 28.330 & (5.273) & 34.170 & $(5.844)$ & 40.830 & (6.395) & 80.830 & (8.994) & 38.498 & (5.844) \\
\hline PHJUNE & 9.170 & (2.822) & 18.330 & (3.830) & 19.170 & (3.937) & 43.330 & (6.597) & 86.670 & (9.308) & 35.334 & (5.299) \\
\hline PHJULY & 9.170 & (2.822) & 18.330 & (3.830) & 19.170 & (3.937) & 100.000 & (10.025) & 100.000 & (10.025) & 49.334 & (6.128) \\
\hline PHSEPT & 10.000 & (2.825) & 15.830 & (3.967) & 23.330 & (4.761) & 22.500 & (4.691) & 25.830 & $(5.050)$ & 19.498 & (4.259) \\
\hline SMAPRIL & 3.330 & (1.448) & 7.500 & (2.503) & 7.500 & $(2.503)$ & 10.000 & (3.137) & 13.330 & (3.669) & 8.332 & (2.652) \\
\hline SMMAY & 5.830 & (2.081) & 16.670 & (4.074) & 23.330 & (4.822) & 30.830 & (5.554) & 65.830 & (8.105) & 28.498 & (4.927) \\
\hline SMJUNE & 10.000 & (3.008) & 9.170 & $(2.718)$ & 11.670 & (3.247) & 34.170 & (5.852) & 65.830 & (8.105) & 26.168 & (4.586) \\
\hline SMJULY & 10.000 & (3.008) & 9.170 & (2.718) & 11.670 & (3.247) & 100.000 & (10.025) & 100.000 & (10.025) & 46.168 & (5.805) \\
\hline SMSEPT & 2.500 & (1.340) & 7.500 & (2.503) & 7.500 & (2.503) & 10.000 & (3.137) & 18.330 & (4.313) & 9.166 & (2.759) \\
\hline MEAN & 9.194 & (2.760) & 16.473 & (3.809) & 19.779 & (4.232) & 41.750 & (6.033) & 60.583 & (7.415) & 29.556 & (4.850) \\
\hline F-LSD(0.05) & & NS & & 1.639 & & 1.190 & & NS & & NS & & \\
\hline
\end{tabular}

$\mathrm{M}=$ Marketer, $\mathrm{P} 76 \mathrm{H}=$ Poinsett 76 Holland, $\mathrm{P} 76 \mathrm{~N}=$ Poinsett 76 Netherlands, $\mathrm{PF}=$ Poinsett France,PH=Poinsett Holland, $\mathrm{S}=\mathrm{Super}$ marketer. Values in parenthesis are squareroot transformed values to which LSD is applicable.

Table 11: The effect of planting time and variety on phytophtora blight disease incidence at different weeks after planting.

\begin{tabular}{|c|c|c|c|c|c|c|c|c|c|c|c|c|}
\hline \multicolumn{13}{|c|}{ WEEKS AFTER PLANTING (WAP) } \\
\hline VAR X MON & \multicolumn{2}{|c|}{ 2WAP } & \multicolumn{2}{|c|}{ 4WAP } & \multicolumn{2}{|c|}{ 6WAP } & \multicolumn{2}{|c|}{ 8WAP } & \multicolumn{2}{|c|}{ 10WAP } & \multicolumn{2}{|c|}{ MEAN } \\
\hline MAPRIL & 0.417 & $(0.909)$ & 0.833 & $(1.125)$ & 0.917 & $(1.155)$ & 0.917 & $(1.155)$ & 1.167 & $(1.284)$ & 0.850 & $(1.126)$ \\
\hline MMAY & 0.833 & $(1.138)$ & 1.333 & (1.344) & 2.583 & $(1.735)$ & 3.333 & (1.939) & 4.000 & $(2.121)$ & 2.416 & (1.655) \\
\hline MJUNE & 0.833 & $(1.1380$ & 1.000 & (1.225) & 1.000 & (1.225) & 3.333 & (1.939) & 4.000 & $(2.121)$ & 2.033 & (1.628) \\
\hline MJULY & 0.833 & $(1.138)$ & 1.000 & (1.225) & 1.000 & $(1.225)$ & 4.000 & $(2.121)$ & 4.000 & $(2.121)$ & 2.167 & (1.566) \\
\hline MSEPT & 0.000 & $(0.707)$ & 0.833 & $(1.139)$ & 1.167 & $(1.284)$ & 1.250 & $(1.314)$ & 1.583 & $(1.433)$ & 0.967 & $(1.175)$ \\
\hline P76HAPRIL & 0.750 & $(1.068)$ & 1.083 & $(1.241)$ & 1.167 & $(1.284)$ & 1.167 & $(1.284)$ & 1.167 & (1.284) & 1.067 & (1.232) \\
\hline P76HMAY & 0.750 & (1.095) & 1.417 & (1.373) & 2.417 & $(1.690)$ & 2.917 & (1.837) & 4.000 & (2.121) & 2.300 & (1.623) \\
\hline P76HJUNE & 1.000 & $(1.225)$ & 1.167 & $(1.284)$ & 1.250 & $(1.314)$ & 2.917 & $(1.837)$ & 4.000 & $(2.121)$ & 2.067 & (1.556) \\
\hline P76HJULY & 1.000 & (1.225) & 1.167 & (1.284) & 1.250 & (1.314) & 4.000 & (2.121) & 4.000 & (2.121) & 2.283 & (1.613) \\
\hline P76HSEPT & 0.250 & $(0.837)$ & 1.167 & (1.284) & 1.167 & (1.284) & 1.167 & (1.284) & 1.500 & (1.403) & 1.050 & (1.218) \\
\hline P76NAPRIL & 0.667 & $(1.052)$ & 0.750 & $(1.095)$ & 1.000 & (1.211) & 1.083 & $(1.254)$ & 1.250 & (1.314) & 0.950 & (1.185) \\
\hline P76NMAY & 0.667 & (1.052) & 1.167 & (1.284) & 1.750 & (1.472) & 1.750 & (1.472) & 4.000 & (2.121) & 1.867 & (1.480) \\
\hline P76N3XJUNE & 0.750 & (1.095) & 1.000 & (1.211) & 1.000 & (1.211) & 1.750 & (1.472) & 4.000 & $(2.121)$ & 1.700 & (1.422) \\
\hline P76NJULY & 0.750 & $(1.095)$ & 1.000 & $(1.211)$ & 1.000 & (1.211) & 4.000 & $(2.121)$ & 4.000 & $(2.121)$ & 2.150 & $(1.552)$ \\
\hline P76NSEPT & 0.667 & (1.0520 & 0.750 & (1.095) & 1.083 & (1.254) & 1.083 & (1.254) & 1.250 & (1.314) & 0.967 & (1.229) \\
\hline PFAPRIL & 1.000 & (1.171) & 1.250 & (1.273) & 1.167 & (1.271) & 1.167 & (1.271) & 1.250 & (1.314) & 1.167 & $(1.260)$ \\
\hline PFMAY & 0.917 & (1.182) & 1.417 & (1.373) & 1.917 & (1.535) & 1.917 & (1.517) & 4.000 & (2.121) & 2.034 & (1.546) \\
\hline PFJUNE & 1.000 & (1.225) & 1.000 & (1.225) & 1.167 & (1.284) & 1.917 & (1.517) & 4.000 & $(2.121)$ & 1.817 & (1.474) \\
\hline
\end{tabular}


Citation: Ishieze PU, Ugwuoke Kelvin I, Aba Simon C (2015) The Effect of Planting Time on Phytophthora Blight Disease Incidence and Severity on Cucumber (Cucumis sativus) in Nsukka, Derived Savanna, Agro Ecology, South Eastern Nigeria. J Plant Pathol Microbiol 6: 318. doi:10.4172/2157-7471.1000318

\begin{tabular}{|c|c|c|c|c|c|c|c|c|c|c|c|c|}
\hline PFJULY & 1.000 & $(1.225)$ & 1.000 & $(1.225)$ & 1.167 & $(1.284)$ & 4.000 & $(2.121)$ & 4.000 & $(2.121)$ & 2.233 & (1.595) \\
\hline PFSEPT & 0.667 & $(1.052)$ & 1.500 & $(1.362)$ & 1.250 & $(1.314)$ & 1.250 & $(1.314)$ & 1.417 & (1.373) & 1.217 & $(1.283)$ \\
\hline PHAPRIL & 1.000 & $(1.211)$ & 1.333 & $(1.344)$ & 1.250 & (1.314) & 1.250 & (1.314) & 1.250 & (1.314) & 1.217 & (1.299) \\
\hline PHMAY & 0.750 & (1.095) & 1.667 & (1.457) & 2.500 & (1.714) & 2.333 & $(1.646)$ & 4.000 & $(2.121)$ & 2.250 & (1.607) \\
\hline PHJUNE & 0.750 & (1.095) & 0.833 & $(1.139)$ & 0.917 & $(1.168)$ & 2.333 & $(1.646)$ & 4.000 & $(2.121)$ & 1.767 & $(1.434)$ \\
\hline PHJULY & 0.750 & $(1.095)$ & 0.833 & $(1.139)$ & 0.917 & (1.168) & 4.000 & $(2.121)$ & 4.000 & $(2.121)$ & 2.100 & (1.529) \\
\hline PHSEPT & 0.917 & $(1.182)$ & 1.333 & (1.344) & 1.250 & $(1.314)$ & 1.250 & (1.314) & 1.500 & (1.403) & 1.250 & (1.311) \\
\hline SMAPRIL & 0.417 & $(0.923)$ & 0.667 & (1.052) & 0.750 & $(1.082)$ & 1.000 & (1.211) & 1.083 & (1.254) & 0.783 & (1.104) \\
\hline SMMAY & 0.500 & $(0.966)$ & 1.000 & (1.225) & 1.500 & (1.403) & 1.583 & (1.427) & 3.917 & $(2.100)$ & 1.700 & (1.424) \\
\hline SMJUNE & 0.917 & (1.168) & 0.667 & (1.052) & 0.833 & (1.139) & 1.583 & (1.427) & 4.000 & (2.121) & 1.600 & (1.381) \\
\hline SMJULY & 0.917 & $(1.168)$ & 0.667 & $(1.052)$ & 0.833 & $(1.139)$ & 4.000 & $(2.121)$ & 4.000 & $(2.121)$ & 2.083 & $(1.520)$ \\
\hline SMSEPT & 0.583 & $(1.009)$ & 0.667 & $(1.052)$ & 1.083 & $(1.254)$ & 1.083 & $(1.254)$ & 1.083 & $(1.254)$ & 0.900 & (1.165) \\
\hline MEAN & 0.742 & $(1.086)$ & 1.050 & (1.224) & 1.275 & (1.308) & 2.178 & (1.588) & 2.914 & $(1.804)$ & 1.632 & (1.402) \\
\hline F-LSD(0.05) & & 0.160 & & 0.144 & & 0.149 & & 0.167 & & NS & & \\
\hline
\end{tabular}

$\mathrm{M}=$ Marketer, $\mathrm{P} 76 \mathrm{H}=$ Poinsett 76 Holland, $\mathrm{P} 76 \mathrm{~N}=$ Poinsett 76 Netherlands, $\mathrm{PF}=$ Poinsett France,PH=Poinsett Holland, $\mathrm{S}=\mathrm{Super}$ marketer. Values in parenthesis are squareroot transformed values to which LSD is applicable.

Table 12: The effect of planting time and variety on phytophtora blight disease severity on leaves at different weeks after planting.

\begin{tabular}{|c|c|c|c|c|c|c|c|c|c|c|c|c|}
\hline \multicolumn{13}{|c|}{ WEEKS AFTER PLANTING (WAP) } \\
\hline VARXMON & \multicolumn{2}{|c|}{ 2WAP } & \multicolumn{2}{|c|}{ 4WAP } & \multicolumn{2}{|c|}{ 6WAP } & \multicolumn{2}{|c|}{ 8WAP } & \multicolumn{2}{|c|}{ 10WAP } & \multicolumn{2}{|c|}{ MEAN } \\
\hline MAPRIL & - & - & - & - & 0.667 & $(1.052)$ & 0.583 & $(1.009)$ & 0.833 & $(1.139)$ & 0.694 & (1.067) \\
\hline MMAY & - & - & - & - & 0.917 & (1.155) & 2.250 & (1.639) & 1.417 & (1.373) & 1.528 & $(1.389)$ \\
\hline MJUNE & - & - & - & - & 0.583 & (1.009) & 0.667 & (1.052) & 1.417 & (1.373) & 0.889 & (1.145) \\
\hline MJULY & - & - & - & - & 0.583 & (1.009) & 4.000 & $(2.121)$ & 4.000 & (2.121) & 2.861 & $(1.750)$ \\
\hline MSEPT & - & - & - & - & 0.833 & $(1.138)$ & 0.833 & $(1.138)$ & 1.000 & (1.225) & 0.889 & $(1.167)$ \\
\hline P76HAPRIL & - & - & - & - & 0.917 & (1.168) & 0.833 & (1.138) & 0.917 & (1.182) & 0.889 & (1.163) \\
\hline P76HMAY & - & - & - & - & 1.000 & $(1.192)$ & 1.500 & $(1.397)$ & 1.500 & (1.397) & 1.333 & (1.329) \\
\hline P76HJUNE & - & - & - & - & 0.833 & $(1.125)$ & 1.000 & $(1.225)$ & 1.333 & (1.344) & 1.055 & $(1.231)$ \\
\hline P76HJULY & - & - & - & - & 0.833 & (1.125) & 4.000 & $(2.121)$ & 4.000 & (2.121) & 2.944 & (1.789) \\
\hline P76HSEPT & - & - & - & - & 1.000 & (1.225) & 1.000 & (1.225) & 1.000 & (1.225) & 1.000 & (1.225) \\
\hline P76NAPRIL & - & - & - & - & 0.333 & $(0.866)$ & 0.750 & $(1.082)$ & 0.917 & $(1.168)$ & 0.667 & $(1.039)$ \\
\hline P76NMAY & - & - & - & - & 0.833 & (1.138) & 1.750 & (1.475) & 1.500 & (1.397) & 1.361 & (1.337) \\
\hline P76N3XJUNE & - & - & - & - & 0.333 & $(0.880$ & 0.583 & $(1.009)$ & 1.250 & $(1.314)$ & 0.722 & (1.162) \\
\hline P76NJULY & - & - & - & - & 0.333 & $(0.880)$ & 4.000 & $(2.121)$ & 4.000 & $(2.121)$ & 2.778 & (1.707) \\
\hline P76NSEPT & - & - & - & - & 0.583 & $(0.996)$ & 1.083 & (1.254) & 1.083 & $(1.254)$ & 0.916 & (1.168) \\
\hline PFAPRIL & - & - & - & - & 0.667 & (1.052) & 1.000 & (1.184) & 0.667 & (1.039) & 0.778 & (1.092) \\
\hline PFMAY & - & - & - & - & 1.000 & $(1.157)$ & 1.333 & $(1.344)$ & 1.417 & $(1.373)$ & 1.250 & $(1.291)$ \\
\hline PFJUNE & - & - & - & - & 0.667 & (1.052) & 0.833 & $(1.138)$ & 1.750 & (1.492) & 1.083 & (1.227) \\
\hline PFJULY & - & - & - & - & 0.667 & (1.052) & 4.000 & (2.121) & 4.000 & (2.121) & 2.889 & (1.765) \\
\hline PFSEPT & - & - & - & - & 0.667 & $(1.052)$ & 1.083 & (1.241) & 1.083 & $(1.254)$ & 0.944 & (1.182) \\
\hline PHAPRIL & - & - & - & - & 0.583 & (1.009) & 0.750 & (1.063) & 1.083 & (1.222) & 0.805 & (1.098) \\
\hline PHMAY & - & - & - & - & 1.333 & (1.316) & 1.833 & (1.502) & 1.583 & (1.433) & 1.583 & (1.417) \\
\hline PHJUNE & - & - & - & - & 0.750 & (1.095) & 0.917 & $(1.168)$ & 1.750 & (1.487) & 1.139 & $(1.250)$ \\
\hline PHJULY & - & - & - & - & 0.750 & (1.095) & 4.000 & $(2.121)$ & 4.000 & (2.121) & 2.917 & (1.779) \\
\hline PHSEPT & - & - & - & - & 0.667 & $(1.052)$ & 0.917 & (1.168) & 1.250 & $(1.308)$ & 0.945 & (1.176) \\
\hline SMAPRIL & - & - & - & - & 0.167 & $(0.793)$ & 0.417 & $(0.923)$ & 0.417 & $(0.923)$ & 0.334 & $(0.880)$ \\
\hline SMMAY & - & - & - & - & 0.667 & $(1.025)$ & 1.667 & $(1.462)$ & 1.167 & $(1.284)$ & 1.167 & $(1.257)$ \\
\hline SMJUNE & - & - & - & - & 0.000 & $(0.707)$ & 0.083 & $(0.750)$ & 1.250 & $(1.314)$ & 0.444 & $(0.924)$ \\
\hline SMJULY & - & - & - & - & 0.000 & $(0.707)$ & 4.000 & $(2.121)$ & 4.000 & $(2.121)$ & 2.667 & $(1.650)$ \\
\hline SMSEPT & - & - & - & - & 0.417 & $(0.923)$ & 1.000 & $(1.225)$ & 1.000 & (1.225) & 0.806 & (1.124) \\
\hline MEAN & - & - & - & - & 0.653 & (1.035) & 1.622 & (1.385) & 1.753 & (1.449) & 1.343 & (1.290) \\
\hline F-LSD(0.05) & - & - & - & - & & NS & & 0.156 & & NS & & \\
\hline
\end{tabular}

$\mathrm{M}=$ Marketer, $\mathrm{P} 76 \mathrm{H}=$ Poinsett 76 Holland, $\mathrm{P} 76 \mathrm{~N}=$ Poinsett 76 Netherlands, $\mathrm{PF}=$ Poinsett France,PH=Poinsett Holland, $\mathrm{S}=\mathrm{Super}$ marketer. Values in parenthesis are squareroot transformed values to which LSD is applicable.

Table 13: The effect of planting time and variety on phytophtora blight disease severity on fruits at different weeks after planting

were superior to Poinsette 76 Holland, Poinsette France and Poinsette Holland. Super marketer, Poinsette 76 Netherlands and Marketer varieties records were low in both the disease incidence, disease severity on both leaves and fruits and yield characters. The Super marketer variety had differential yield characters-fruit girth, weight of fruit plant and fruit lengths, which were significantly different from the other varieties. These differential growth and yield characters of cucumber have been reported by researchers in different parts of the world. The differences in vegetative and yield characters can be attributed to genetic composition of the varieties used; the Ashley variety may have 
Citation: Ishieze PU, Ugwuoke Kelvin I, Aba Simon C (2015) The Effect of Planting Time on Phytophthora Blight Disease Incidence and Severity on Cucumber (Cucumis sativus) in Nsukka, Derived Savanna, Agro Ecology, South Eastern Nigeria. J Plant Pathol Microbiol 6: 318. doi:10.4172/2157-7471.1000318

\begin{tabular}{|c|c|c|c|c|c|c|}
\hline VAR X MON & $\mathrm{FG}(\mathrm{cm})$ & $\mathrm{FL}(\mathrm{cm})$ & FW/PIt(kg) & NFPP & $F Y(t / h a)$ & $\mathrm{DF}(\mathrm{t} / \mathrm{ha})$ \\
\hline MAPRIL & 4.958 & 20.217 & 2.259 & 5.484 & 451.80 & 2.259 \\
\hline MMAY & 2.392 & 10.781 & 0.209 & 1.950 & 41.90 & 0.209 \\
\hline MJUNE & 2.425 & 10.843 & 0.185 & 1.692 & 37.00 & 0.185 \\
\hline MJULY & 2.258 & 10.843 & 0.119 & 1.986 & 23.70 & 0.119 \\
\hline MSEPT & 4.958 & 20.217 & 2.397 & 5.475 & 479.30 & 2.397 \\
\hline P76HAPRIL & 4.833 & 19.590 & 2.371 & 5.614 & 474.20 & 2.371 \\
\hline P76HMAY & 2.125 & 11.696 & 0.200 & 2.054 & 40.00 & 0.200 \\
\hline P76HJUNE & 2.525 & 11.340 & 0.182 & 1.963 & 36.40 & 0.182 \\
\hline P76HJULY & 2.525 & 11.340 & 0.117 & 1.946 & 23.40 & 0.117 \\
\hline P76HSEPT & 4.833 & 19.590 & 2.514 & 5.788 & 502.70 & 2.514 \\
\hline P76NAPRIL & 4.977 & 19.813 & 2.302 & 5.475 & 460.40 & 2.302 \\
\hline P76NMAY & 2.425 & 12.536 & 0.162 & 2.314 & 32.40 & 0.162 \\
\hline P76N3XJUNE & 2.467 & 11.798 & 0.151 & 2.328 & 30.20 & 0.151 \\
\hline P76NJULY & 2.467 & 11.798 & 0.076 & 1.886 & 15.20 & 0.076 \\
\hline P76NSEPT & 4.977 & 19.813 & 2.313 & 5.380 & 462.60 & 2.313 \\
\hline PFAPRIL & 5.256 & 20.098 & 2.445 & 5.288 & 488.90 & 2.445 \\
\hline PFMAY & 2.350 & 12.441 & 0.161 & 2.460 & 32.20 & 0.161 \\
\hline PFJUNE & 2.800 & 11.606 & 0.157 & 2.379 & 31.50 & 0.157 \\
\hline PFJULY & 2.533 & 11.606 & 0.079 & 2.134 & 15.70 & 0.079 \\
\hline PFSEPT & 5.256 & 20.098 & 2.449 & 5.614 & 489.70 & 2.449 \\
\hline PHAPRIL & 5.143 & 19.491 & 2.539 & 5.383 & 507.90 & 2.539 \\
\hline PHMAY & 2.242 & 12.493 & 0.158 & 2.373 & 31.60 & 0.158 \\
\hline PHJUNE & 2.550 & 11.406 & 0.122 & 2.314 & 24.50 & 0.122 \\
\hline PHJULY & 2.500 & 11.406 & 0.075 & 2.042 & 15.10 & 0.075 \\
\hline PHSEPT & 5.143 & 19.491 & 2.292 & 5.484 & 458.30 & 2.292 \\
\hline SMAPRIL & 5.806 & 20.852 & 2.531 & 5.788 & 508.90 & 2.531 \\
\hline SMMAY & 2.767 & 14.207 & 0.175 & 2.473 & 35.00 & 0.175 \\
\hline SMJUNE & 2.567 & 12.658 & 0.171 & 2.200 & 34.10 & 0.171 \\
\hline SMJULY & 2.354 & 12.658 & 0.107 & 1.898 & 21.50 & 0.107 \\
\hline SMSEPT & 5.806 & 20.852 & 2.696 & 5.722 & 506.20 & 2.550 \\
\hline MEAN & 3.541 & 15.119 & 1.057 & 3.496 & 210.41 & 0.075 \\
\hline F-LSD(0.05) & 0.341 & 0.514 & 0.1757 & NS & NS & NS \\
\hline
\end{tabular}

$\mathrm{M}=$ Marketer, $\mathrm{P} 76 \mathrm{H}=$ Poinsett 76 Holland, $\mathrm{P} 76 \mathrm{~N}=$ Poinsett 76 Netherlands, $\mathrm{PF}=$ Poinsett France, $\mathrm{PH}=$ Poinsett Holland, $\mathrm{S}=$ Super marketer. $\mathrm{FG}=$ Fruit girth, $F L=F r u i t$ length, $F W=F r u i t$ weight, NFPP=Number of fruit per plant and $F Y=F r u i t$ yield, DF=Diseased fruits

Table 14: The effect of planting time and variety on the yield of six varieties of cucumber.

been quicker in adapting to the environment than the other varieties or the vegetative characters of the Ashley variety may have been more active than the other varieties and therefore had a strong source to sink relationship which resulted in high yields experienced in the variety. The number of fruits per plant was higher than what was reported by Phu [6] and by Jizhe [7] in Thailand. The yields obtained in this varietal studies was higher than what Manyvong and Phu [8] reported in Thailand but the same as the yield obtained by Mingbao [9].

From the result of this study, it was found that cucumber can be planted at any time of the rainy season because of the consistent high yields recorded in the varietal trials which were carried out in different months of April, May, June, July and September in 2013. This is in consonance with the findings of Mas who stated that cucumber can be planted at any time of the year provided during the growing period, there is ample moisture and the soil is fertile. The results also agree with the findings of Thoa [10] who observed that cucumber can be planted at anytime of the year and that even in temperate regions, during the winter the crop can be grown under greenhouse conditions using artificial lighting systems. The high yield which was consistently recorded by the Super Marketer variety throughout the five months of study could be attributed to the genetic composition and its ability to quickly adapt to this environment. Super marketer produced the highest yield per hectare, and the Poinsette Holland, the lowest.

\section{The cumulative effect of variety and time of planting on phytophthora blight disease incidence, severity and yield of cucumber.}

The observed significant $(p<0.05)$ variation in the varieties of cucumber (marketer, super marketer, poinsette 76 Holland and Netherlands, poinsette France and Holland) and the time of planting (April, May, June, July and September) having Supermarketer planted in the month of April, is attributed to the genetic make up of this particular variety and environmental condition [5] during the time it was planted. Generally, the varieties planted during the month of April gave the best results as regards the disease incidence, severity on leaves and fruits and the total yield, closely followed by those planted during the month of September. The month of July gave the poorest results; this reflects the substantial contribution of environmental condition in controlling the introduction and subsequent spread of the disease if occurred in a field. The month of July had more rain days and length (19.00 and 283.96) respectively, and these played a significant role on the spread of the disease. Furthermore, the month of July had low temperature and high humidity which helps in spreading phytophthora blight very fast in a crop field [5]. This result also tallied with the assertion of Agrios [11] that the higher the moisture content of the soil and lower the temperature, the higher the spread of phytophthora blight disease of cucurbits. The yield (508.90 t/ha) recorded for the super marketer during the month of April remains the highest, therefore super marketer remains the best variety while April is the best time to grow cucumber in this derived savannah agroecology of Nsukka.

\section{References}

1. Wehner TC, Guner N (2004) Growth stage, flowering pattern, yield and harvest date prediction of four types of cucumber tested at 10 planting dates. Acta Hort 637.

2. Adetula O, Denton $L$ (2003) Performance of vegetative and yield accessions of cucumber (Cucumis sativa L.) Horticultural Society of Nigeria (HORTSON) Proceedings of 21 st annual conference.

3. Obi IU (2002) Statistical methods in detecting differences between treatmen means and Research methodology issues in laboratory and field experiment. Second edition p. 41

4. Papadopoulos AP (1994) Growing greenhouse seedless cucumbers in soilless media Research centre, Harrow, Ontario Canada.

5. Babadoost M (2005) Phytophthora blight of cucurbits. The Plant Health Instructor.

6. Phu NT (1998) Nitrogen and potassium effect on cucumber yield. ARC/AVRDC Training Bangkok Thailand.

7. Jizhe C (1993) Cucumber evaluation trial .ARC/AVRDC Training Thailand

8. Manyvong V (1997) Cucumber varietal trial ARC/AVRDC Training workshop Thailand.

9. Mingbao L (1991) Cucumber varietal trial.ARC/AVRDC Training Bangkok Thailand.

10. Thoa DK (1998) Cucumber seed Multiplication and characterization A.R.CAVRDC Research Report. Bangkok Thailand.

11. Agrios George N (2004) Plant pathology /5th ed. Elsevier Academic Press 30 Corporate Drive, Suite 400, Burlington, MA 01803, USA 